\title{
Sheep grazing and plant cover dynamics of a shadscale community
}

\author{
HUMBERTO ALZÉRRECA-ANGELO, EUGENE W. SCHUPP, AND STANLEY G. KITCHEN
}

Authors are range consultant, Casilla 13697, La Paz, Bolivia; assistant professor, Department of Rangeland Resources and the Ecology Center, Utah State University, Logan, Utah 84322-5230; and botanist, U.S.D.A. Forest Service, Intermountain Research Station, Shrub Sciences Laboratory, Provo, Utah 84606. At the time of the research, the senior author was research assistant, Department of Rangeland Resources, Utah State University. Address reprint requests and all other correspondence to the second author. This research was funded by the Bolivian Institute of Agricultural Technology; the Small Ruminant Cooperative Research Suppon Progrum; the USDA. Forest Service Intermountain Research Station; the Utah State University Ecology Center; and the Utah Agricultural Experiment Station (UAES), Utah State University, Logan, Utah 84322-4810.

Abstract

Despite extensive coverage and long-term use, the extent to which shadscale [Atriplex confertifolia (Torr. \& Frem.) Wats.] community dynamics are driven by grazing rather than by climate and inherent plant characteristics is unresolved. We analyze a 59-year data set from the Desert Experimental Range, southwestern Utah, with the objective of discriminating between grazing and non-grazing effects on cover dynamics. Canopy cover of $(5 \times 20 \mathrm{ft}) 9.3 \mathrm{~m}^{2}$ plots were estimated in 1935,1958 , 1969,1975 , and 1994. Treatments were time (5 dates), grazing (ungrazed versus grazed), and season (spring versus winter). Time was significant; total cover initially increased following release from uncontrolled grazing and improvement of climate (1935-58, $P<0.001)$, remained unchanged over the following dry interval (1958-69, $P=1.000)$, increased over a drier interval (1969-75, $P<0.001)$, and then decreased dramatically over the final wet period (1975-94, $P<0.001)$. Grazing was also significant $(P<0.001)$, but cover of ungrazed plots exceeded that of grazed plots only in 1975 and $1994(\mathrm{P} \leq \mathbf{0 . 0 3 3})$. The 6 dominant species showed varying responses to grazing and time, with some responding primarily to grazing (e.g., budsage, Artemisia spinescens D.C. Eaton in Wats.) and others responding primarily to time (climate, longevity, etc., e.g., Indian ricegrass, Oryzopsis hymenoides R. \& S.). Similarly, seasonal effects were not universal. Shrub cover initially increased and then declined dramatically while grass cover monotonically increased. Results suggest that release from uncontrolled grazing coupled with improving climatic conditions were responsible for initial recovery of the community, but that over time, climate and inherent plant traits (e.g., longevity, establishment ecology, etc.) became relatively more important. For total cover and for many individual species, continued grazing affected the rate more than the direction of vegetation change.

Key Words: Artemisia spinescens, Atriplex confertifolia, Ceratoides lanata, climate, Hilaria jamesii, Oryzopsis hymenoides, Sporobolus cryptandrus, vegetation dynamics

Approved as UAES journal paper no. 5047. We thank B. Norton for guidance in the initial stages of this project, D. Sisson for statistical consultations, and L. Coppock, D.A. Johnson, A. Rasmussen, D.W. Roberts, and J. Thomas for improving earlier versions of the manuscript, and J. Powell and 2 anonymous reviewers for help with the final version.

Manuscript accepted 27 July 1997
Resumen

A pesar de la extensa cobertura y prolongado uso de las comunidades de "shadscale" [A. confertifolia (Torr. \& Frem.) Wats.], su dinámica, influenciada por practicas pastorales más que por clima y características vegetales propias, está sin resolver. En este trabajo, analizamos 59 años de datos tomados en el "Desert Experimental Range," al sudoeste de Utah, con el objetivo de discriminar entre los efectos de pastoreo y no pastoreo en la dinámica de la cobertura vegetal. La cobertura de parcelas de $(5 \times 20$ pies) $9.3 \mathrm{~m}^{2}$ fue estimada en $1935,1958,1969,1975$, y 1994. Las tratamientos fueron tiempo ( 5 fechas), pastoreo (no pastoreo vs. pastoreo), y estación (primavera vs. invierno). Tiempo fue significativo; la cobertura total aumentó inicialmente despues de la supresión del pastoreo no controlado y de una mejora en las condiciones climáticas $(1935-58, P<0.001)$, permaneciendo constante durante el siguiente intervalo menos húmedo (1958-69, $\mathrm{P}$ $=1.000$ ), aumentó durante el siguiente periodo mas seco (1969-75, $\mathrm{P}<0.001)$, disminuyendo después drásticamente durante el último intervalo húmedo $(1975-94, P<0.001)$. Pastoreo resultó también significativo $(P<0.001)$, aunque la cobertura de parcelas no pastadas excidió la de pastadas solamente en 1975 y 1994 ( $P \leq \mathbf{0 . 0 3 3})$. Las seis especies dominantes mostraron respuestas varias al pastoreo $\mathbf{y}$ al tiempo, algunas respondieron principalmente al pastoreo (e.g., "budsage," Artemisia spinescens D.C. Eaton in Wats.) y otras al tiempo en primer lugar (clima, longevidad, etc., e.g., "Indian ricegrass," Oryzopsis hymenoides). Paralelamente, los efectos de la estación no fueron tampoco unánimes. La cobertura de arbustos aumentó inicialmente para después disminuir drásticamente, mientras que la cobertura de hierbas lo hizo uniformemente. Estos resultados sugieren que el cese de pastoreo no controlado conjuntamente con una mejora de las condiciones climáticas fueron la causa responsable de una recuperacion inicial de la comunidad, aunque a lo largo del tiempo, el clima y las propiedades intrinsecas de la vegetación (e.g., longevidad, ecología, etc.) serían relativamente más importantes. El pastoreo continuo afectó la tasa de la cobertura total de muchas especies más que la dirección en el cambio de vegetación.

Despite widespread occurrence and their extensive use, salt desert shrub community dynamics in the western USA are poorly understood (Turner 1971, Rice and Westoby 1978, Branson 1985, Laycock 1994). Perhaps the most thoroughly studied site to date 
is a shadscale [Atriplex confertifolia (Torr. \& Frem.) Wats.] community at the U.S. Forest Service Desert Experimental Range (DER) in southwestern Utah, which has been subjected to sheep grazing trials since 1935. Even at this site, however, there is no consensus as to the major factor or factors affecting vegetation change. While some argued that grazing was the main force driving vegetation dynamics (Hutchings 1966, Holmgren and Hutchings 1972, Harper et al. 1990, Whisenant and Wagstaff 1991, Kitchen and Hall 1996), others suggested that climate and other factors probably have a greater role than grazing in community change (Norton and Bermant 1977, Norton and Michack 1978, Norton 1978).

Long-term data sets coupled with consideration of climatic influence will help separate effects of grazing from those of other factors. This study addresses these needs by adding 19 years to the existing DER data base, and by incorporating a consideration of climatic dynamics (Alzérreca-Angelo 1996). The objective was to distinguish between grazing and non-grazing effects on the cover dynamics of a shadscale community. We use total plant cover and cover of 6 dominant species to describe 59 years of vegetation change in grazed and ungrazed pastures. Specifically, we ask: (1) Does grazing have a long-term effect on plant cover? (2) Is there evidence that other factors such as precipitation regimes have major effects on cover dynamics? (3) Is there an interaction between grazing and time, suggesting that the effects of grazing are dependent on other factors? (4) Is there evidence to support either the classic model of rangeland succession or the alternative of stable states and transitions (Laycock 1991, Kitchen and Hall 1996) in salt desert communities? By extending the long-term data base 19 years we show dramatic and unexpected changes in cover dynamics. Despite these changes, we continue to suggest that controlled grazing is functioning as intended. With proper management, it appears that grazing has relatively minor impacts on cover dynamics in these shrub communities.

\section{Materials and Methods}

\section{Study Area}

The study area has a mean elevation of 1,600 m.a.s.l. and is located at $38^{\circ} 36^{\prime} \mathrm{N}$ and $113^{\circ} 45^{\prime} \mathrm{W}$ at the DER in southwestern Millard County, Utah, about $75 \mathrm{~km}$ west of Milford. The vegetation of the area is representative of the region's $180,000 \mathrm{~km}^{2}$ of winter grazing lands (Holmgren 1973, Gardiner and Norton 1983, Smith 1986). Mean annual temperature is $9.4^{\circ} \mathrm{C}$ with monthly means from $-3.5^{\circ} \mathrm{C}$ in January to $23.3^{\circ} \mathrm{C}$ in July. Mean precipitation is $165 \mathrm{~mm}$, with $\approx 65 \mathrm{~mm}$ in October-March, mainly as snow (winter), $\approx 44 \mathrm{~mm}$ in April-June (spring), and $\approx 56 \mathrm{~mm}$ in July-September (summer). Annual precipitation is highly variable $(\mathrm{CV}=31 \%, \mathrm{n}=61 \mathrm{yr})$, with 1 to several years of belowaverage precipitation alternating with 1 to several years of aboveaverage precipitation (Alzérreca-Angelo 1996). A 17-year moving average revealed an underlying longer-term cycle with aboveaverage precipitation early in the study followed by several decades of below-average precipitation before returning to aboveaverage conditions by the end of the study (Alzérreca-Angelo 1996). Considering primarily winter and spring precipitation because of their importance for the establishment, survival, and growth of new plants necessary for recovery, we classify the 4 intervals of this study as average (1935-58), dry (1958-69), driest (1969-75), and wet (1975-94) (Fig. 1).

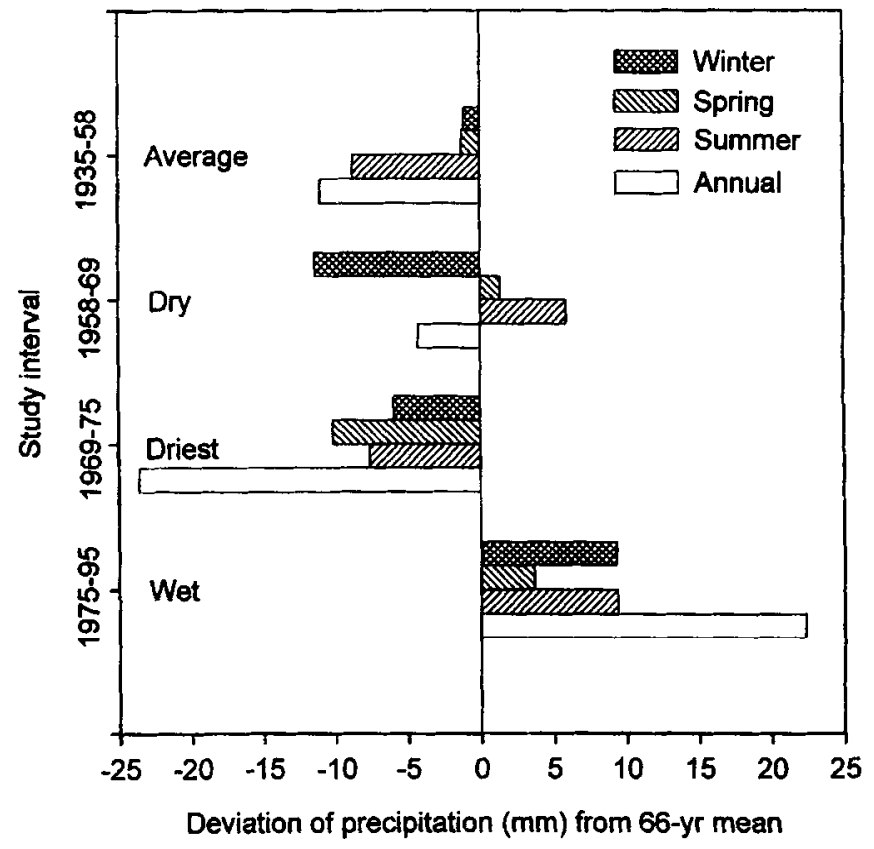

Fig. 1. Mean deviations of seasonal and annual precipitation for each study interval from 62-year means based on DER hydrological year (1 Sept.-30 Oct.) data. The 1935-58 interval was defined as average because of the biological importance of winter and spring precipitation for establishment and growth of most species in this study; note that for some species, however, summer precipitation is more relevant.

The site is in a closed-drainage valley on coalescing alluvial fans, or "bajadas", with slopes of up to $15 \%$. Soils of experimental pastures are Aridisols (haplocambids and haplocalcids-deep, loamy-skeletal, carbonatic group) and Entisols (torrifluvents and torrisamments-deep, coarse-loamy mixed group) with a mean $\mathrm{pH}=8.0$ (range $=7.7-8.6$ ). All are saline-sodic at $45-55 \mathrm{~cm}$ depth. Electrical conductivity is $1 \mathrm{mmho} / \mathrm{cm}$ in upper layers and increases to $40 \mathrm{mmho} / \mathrm{cm}$ at $45 \mathrm{~cm}$ depth (Smith 1986, Holmgren 1973, Brewster 1968, Tew et al. 1997).

The site is dominated by shrubs with intermixed bunchgrasses and rhizomatous grasses (Holmgren 1973, West 1979, Norton 1978, Goodrich 1986, Smith 1986, Harper et al. 1996, Kitchen and Hall 1996). Dominant shrubs include At. confertifolia, Ceratoides lanata (Pursh) J.T. Howell (winterfat), and Artemisia spinescens D.C. Eaton in Wats. (budsage). Dominant perennial grasses are Oryzopsis hymenoides R. \& S. (Indian ricegrass), Hilaria jamesii (Torr.) Benth. (galleta), Sporobolus cryptandrus (Torr.) Gray (sand dropsced), and S. contractus A.S. Hitch. (spike dropseed). Common annuals are Bromus tectorum L. (cheatgrass), Halogeton glomeratus (Bieb.) Mey in Ledeb. (halogeton), and Salsola spp. (Russian thistle), and the most common perennial forb is Sphaeralcea grossularifolia (Hook. \& Am.) Rydb. (globemallow).

\section{The Experiment}

During 1934-35, two 0.24-ha sites (ungrazed) were randomly selected and fenced and 2 nearby unfenced (grazed) companion sites with matching vegetation were permanently marked in 16 of 20 pastures, each 97 or 130 -ha. Two permanent $9.3 \mathrm{~m}^{2}$ plots were 
established within each exclosure and each grazed companion site. Plots were established using units of feet $(5 \times 20 \mathrm{ft}=9.3$ $\mathrm{m}^{2}$ ), and these units are retained for consistency (Hutchings and Stewart 1953).

Canopy cover of individual plants, defined as the vertical projection of plant canopy, were mapped in 128 plots in 1935 using the chart technique on a $3.0 \times 3.0 \mathrm{~cm}(0.1 \times 0.1 \mathrm{ft})$ grid. Plots were remapped in the summers of $1958,1969,1975$, and 1994. Pastures used in this study include 3 grazing intensities (originally 25,35 , or 42 sheep/day/ha, but annually adjusted based on available forage) and 5 "seasons" falling within an overall 15 November-10 April grazing season (fall, fall-spring, fall-winter, winter, and winter-spring).

\section{Total Plant Cover Dynamics}

Total cover was the summed cover of all perennial plants in a plot. A preliminary analysis showed no effect of grazing season in any year (all $P \geq 0.050$ ) so seasons were pooled. Since our major focus was the importance of grazing relative to other factors driving cover changes, grazing intensities were also pooled. Analysis was with a factorial ANOVA with repeated-measures factors (sampling years, or time) and between-group factors (grazing treatments) $(n=64$ grazed and 64 ungrazed plots/year, or 640 total observations) using SAS PROC MIXED (Bonferroni test) which allowed multiple comparisons while controlling the experimentwise error rate at $P=0.050$ (Hatcher and Stepanski 1994). Both time and grazing treatment were analyzed as fixed effects.

\section{Individual Species Cover Dynamics}

In contrast to total cover, individual species may respond more to season of grazing than to intensity of grazing (Harper 1959, Blaisdell and Holmgren 1984, Smith 1986, Clary and Holmgren 1987, Harper et al. 1990, Marble 1990, Whisenant and Wagstaff 1991, Chambers and Norton 1993, Kitchen and Hall 1996). Consequently, we again pooled grazing intensities, but distinguished "spring" (fall-spring and winter-spring) and "winter" (fall, fall-winter, and winter) grazing seasons. The experimental design had 2 seasons, 2 grazing treatments, and 5 sampling years, with 20 pairs of grazed and ungrazed plots in spring pastures and 44 pairs in winter pastures. Analysis was with SAS PROC MANOVA (SAS Institute Inc. 1988, Hatcher and Stepanski 1994) using 6 dominant species (see below) as multivariate variables. Log transformations improved, but did not solve problems of normality and homoscedasticity. We continued the analysis, however, because: (1) MANOVA is robust to moderate violation of these assumptions (Stevens 1966), (2) symmetry was improved, and (3) sample sizes were relatively large.

Species used were the shrubs At. confertifolia (65\% relative cover in 1935), C. lanata (15\%), and Ar. spinescens (4\%), and the grasses $S$. cryptandrus $(6 \%), H$. jamesii $(6 \%)$, and $O$. hymenoides (1\%). Together they comprised $97 \%$ (1935), $98 \%$ (1958), 94\% (1969), 94\% (1975), and 87\% (1994) of the total vegetation cover.

Because of the significance of critical multivariate interactions, we also conducted univariate factorial ANOVA analyses to explore individual species responses. In these analyses time, grazing treatment, and season were analyzed as fixed effects. Because of the factorial structure, analysis of season effects compared all spring plots (grazed + ungrazed controls) with all winter plots (grazed + ungrazed cuntruls). When only "season" is referred to in the results, we are considering this effect. Comparisons of spring-grazed with winter-grazed treatments were based on planned contrasts between these 2 treatment combinations and consider only the overall effect (i.e., across all censuses rather than for individual censuses). Presentations of these comparisons in the results specifically refer to spring-grazed and winter-grazed treatments.

\section{Shrub-Grass Interface}

To better understand the shrub-grass interface through time, we repeated the MANOVA to analyze the data considering only 2 variables: total shrub cover and total perennial grass cover.

\section{Results}

\section{Total Plant Cover Dynamics}

The overall treatment by time interaction was significant $(P=$ 0.034 , Fig. 2) due to a significant interaction over the $1969-75$ interval $(P<0.001)$ when cover increased in ungrazed $(P=$ $0.004)$ but not grazed plots $(P=0.150)$; cover of grazed and ungrazed treatments diverged significantly during this interval. Consequently, post-hoc contrasts revealed no differences between treatments the first 3 dates (all $P \geq 0.453$ ), but greater cover in ungrazed plots in $1975(\mathrm{P}=0.033)$ and $1994(\mathrm{P}<0.001)$. These latter differences yielded a significant overall grazing treatment effect $(P<0.001)$. Time was also significant $(P<0.001)$ and post-hoc contrasts revealed lower cover in 1935 than in any other year (all $\mathrm{P}<0.001$, Fig. 2). Changes in cover were not constant, however. Cover increased between 1935 and $1958(\mathrm{P}<0.001)$, remained unchanged between 1958 and $1969(P=1.000)$, increased again between 1969 and 1975 ( $\mathrm{P}<0.001$ ), and decreased between 1975 and 1994 ( $P<0.001$, Fig. 2).

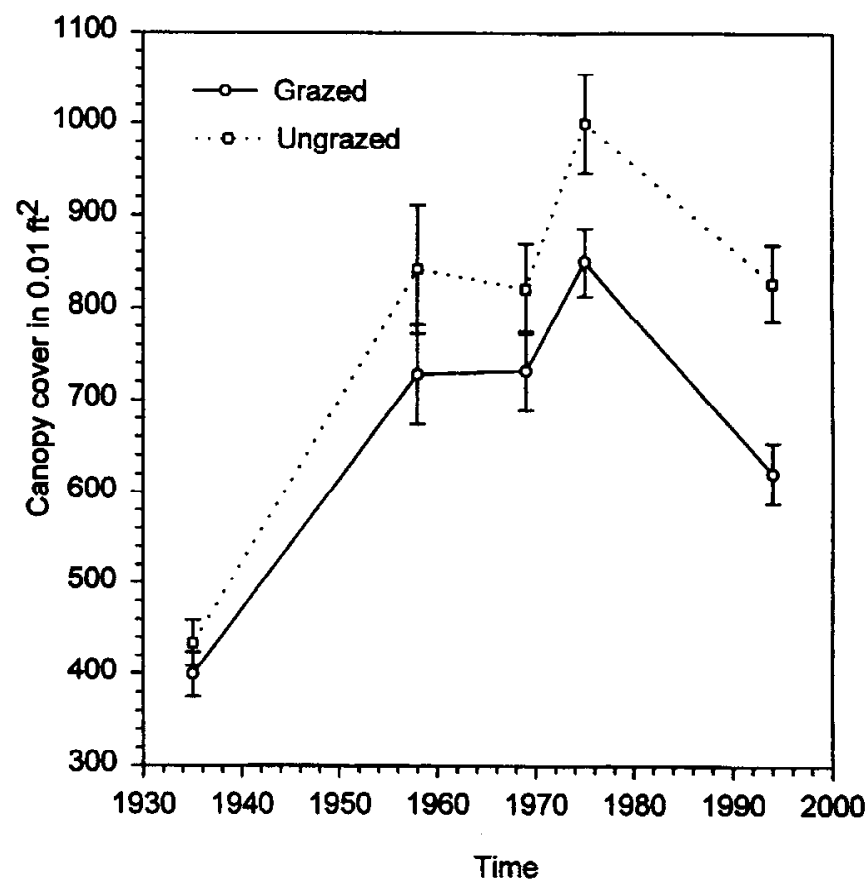

Fig. 2. Dynamics of total plant cover on grazed and ungrazed plots at the DER. Vertical bars are standard errors of the means. Although these SEs reliably represent dispersion of the data, probabilities reported in the text are more valid and meaningful regarding mean separations. 
Individual Species Cover Dynamics - Multivariate Analysis

Time $\times$ grazing $(P=0.001)$ and season $\times$ grazing $(P<0.001)$ interactions were significant, while time $\times$ season $(P=0.322)$ and time $\times$ grazing $\times$ season $(P=0.940)$ interactions were not. Time $(P<0.001)$, grazing $(P<0.001)$, and season $(P<0.001)$ main effects were all significant.

\section{Individual Species Cover Dynamics-Univariate Analysis Atriplex confertifolia}

Only time and grazing main effects were significant (Table 1). Cover did not change between 1935 and 1958, but then decreased significantly across each successive census interval (Fig. 3). The rate of decrease depended on grazing; grazed plots had greater cover than ungrazed plots in $1958(\mathrm{P}=0.045), 1969(\mathrm{P}<0.001)$, and $1975(\mathrm{P}=0.008)$, but by 1994 treatments again did not differ $(P=0.350$, Fig. 4). Within seasons, grazed plots had greater overall cover than ungrazed plots in spring $(P<0.001)$, but not in winter pastures $(P=0.052$, Fig. 6$)$.

\section{Ceratoides lanata}

Time, season, and grazing were significant, but their interactions were not (Table 1). Cover increased between 1935 and $1958(\mathrm{P}=$ 0.044 ), remained unchanged between 1958 and 1975 , and then decreased by $1994(\mathrm{P}<0.001)$ to a value that did not differ from that found in $1935(\mathrm{P}=0.130$, Fig. 3). Despite significance of the overall grazing effect, treatments did not differ in any individual year (all $P \geq 0.110$, Fig. 4). Seasons differed only in 1969 , with greater cover in winter than spring pastures $(P=0.048$, Fig. 5). Grazing did not affect overall cover values in either season (all $P \geq$ 0.059 , Fig. 6).

Table 1. Results of univariate ANOVA of cover of dominant shrub species.

\begin{tabular}{lrrrrrrr}
\hline \hline \multirow{2}{*}{ Source } & \multicolumn{3}{c}{ At. confertifolia } & \multicolumn{2}{c}{ C. lanata } & \multicolumn{2}{c}{ Ar. spinescens } \\
\cline { 2 - 8 } & MS & \multicolumn{1}{c}{$\mathrm{P}$} & \multicolumn{1}{c}{ MS } & P & MS & P \\
\hline Time & 73.81 & $<0.001$ & 39.71 & $<0.001$ & 17.99 & $<0.001$ \\
Graze & 40.11 & $<0.001$ & 30.00 & 0.016 & 439.30 & $<0.001$ \\
Time*graze & 5.01 & 0.082 & 3.36 & 0.620 & 34.14 & $<0.001$ \\
Season & 0.58 & 0.623 & 27.15 & 0.021 & 125.31 & $<0.001$ \\
Time*season & 1.39 & 0.681 & 2.02 & 0.811 & 9.77 & 0.037 \\
Graze*season & 8.74 & 0.057 & 2.58 & 0.477 & 111.01 & $<0.001$ \\
Time*graze*season & 1.36 & 0.688 & 0.46 & 0.986 & 6.52 & 0.144 \\
Error & 2.41 & & 5.09 & & 3.79 & \\
\hline
\end{tabular}

\section{Artemisia spinescens}

In addition to main effects, time $\mathrm{x}$ grazing, season $\mathrm{x}$ grazing, and time $\times$ season interactions were significant (Table 1). Cover increased between 1935 and $1958(P=0.002$, Fig. 3) and then remained unchanged. By treatment, cover increased in ungrazed plots $(\mathrm{P}<0.001$, Fig. 4) between 1935 and 1958; although no other increases across individual intervals were significant, the cumulative increase between 1958 and 1994 was $(P=0.029)$. In contrast, cover of grazed plots did not change throughout the study $(P=0.956$, Fig. 4$)$. As a result, the time $\times$ grazing interaction was significant across the first interval $(P=0.003)$, and ungrazed plots had greater cover than grazed plots at all post1935 censuses (all P < 0.001, Fig. 4). Similarly, cover was greater in winter than spring plots in all post-1935 censuses (all $\mathrm{P}<$ 0.028 , Fig. 5), and grazing significantly decreased overall cover
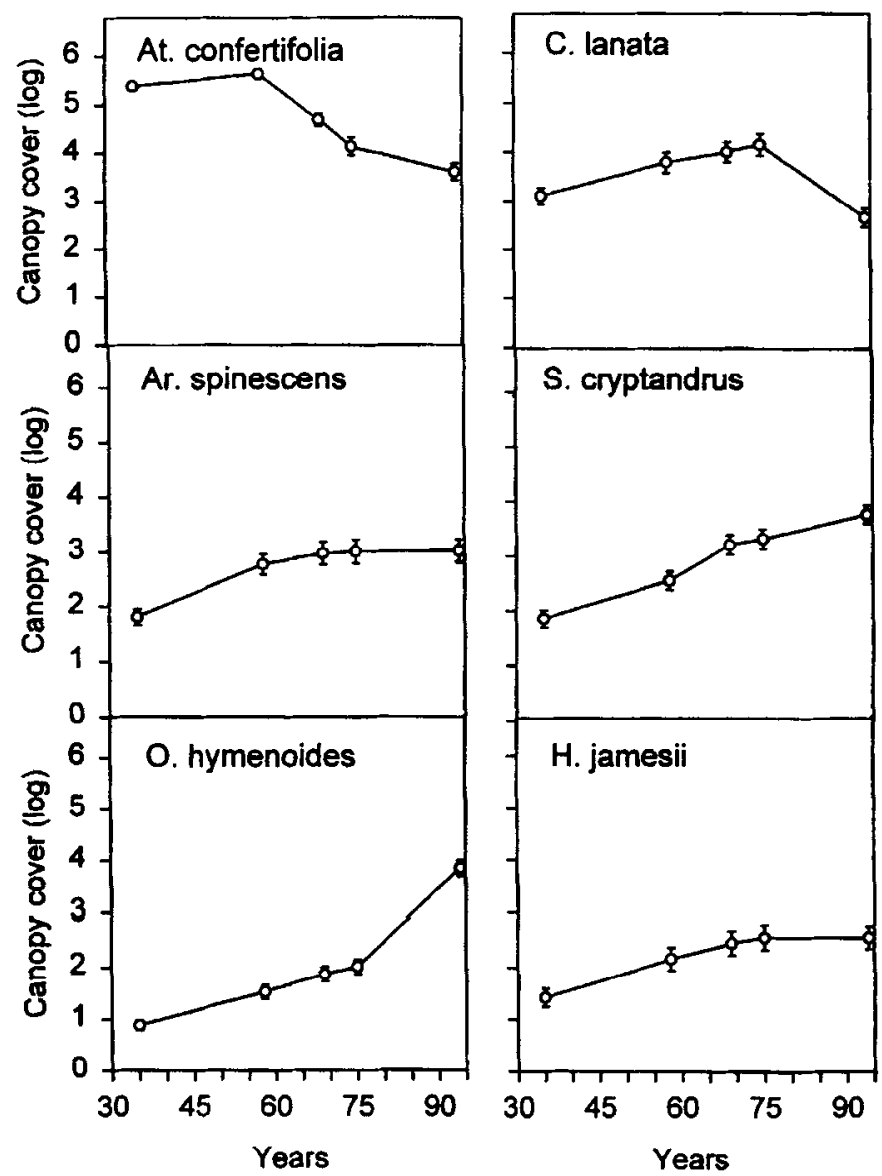

Fig. 3. Main effects of time on log-transformed cover of six dominant species at the DER. Vertical bars are standard errors of the means. Although these SEs reliably represent dispersion of the data, probabilities reported in the tables and text are more valid and meaningful regarding mean separations.

in both seasons (both $\mathrm{P}<0.001$, Fig. 6).

\section{Sporobolus cryptandrus}

Only the main effects time, season, and grazing were significant (Table 2). Cover increased across all intervals (all $\mathrm{P} \leq$ 0.044) except the short dry $1970-75$ period $(P=0.559$, Fig. 3$)$. Despite a significant overall grazing effect, grazing treatments did not differ for any individual census (all $\mathrm{P} \leq 0.099$, Fig. 4). Cover was greater in winter than spring pastures only in $1969(\mathrm{P}$ $=0.044$, Fig. 5). Overall cover was greater in winter-grazed than spring-grazed plots ( $P=0.044$, Fig. 6$)$, but the comparison is invalid because although winter and spring ungrazed controls had equal cover in $1935(P=0.942)$, winter controls had greater cover than spring controls by $1994(\mathrm{P}=0.0414$, Fig. 6 ), suggesting pastures were diverging independent of grazing. This interpretation is supported hy the lack of a grazing effect either season (both $P$ $\geq 0.138$, Fig. 6).

\section{Oryzopsis hymenoides}

This C-3 cool-season grass had significant effects for time only (Table 2). Cover increased between 1935 and $1958(\mathrm{P}=0.003)$, and again between 1975 and 1994 ( $\mathrm{P}<0.001$, Fig. 3). 

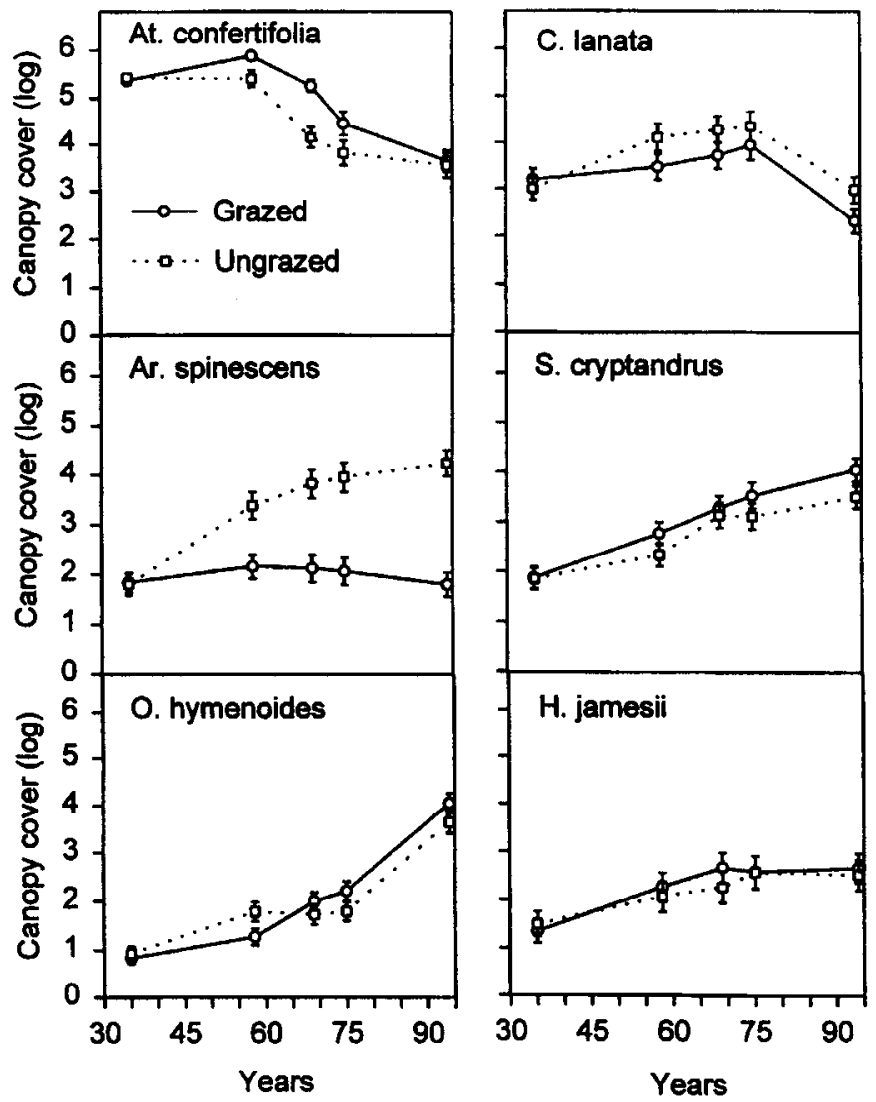

Fig. 4. Grazing $\times$ time effects on log-transformed cover of six dominant species at the DER. Vertical bars are standard errors of the mean. Although these SEs reliably represent dispersion of the data, probabilities reported in the tables and text are more valid and meaningful regarding mean separations.

\section{Hilaria jamesii}

Time and season were significant for this warm-season grass (Table 2). The time effect was due to an increase in cover between 1935 and $1958(\mathrm{P}=0.015$, Fig. 3). Cover was greater for spring plots than for winter plots from 1969 until the end of the study (all $P \leq 0.024$, Fig. 5). Overall cover was greater for spring-grazed than for winter-grazed plots ( $\mathrm{P}<0.001$, Fig. 6), but like $S$. cryptandrus, this comparison is invalid because winter and spring ungrazed controls had similarly diverged by $1994(\mathrm{P}=0.002$, Fig. 6); grazed and ungrazed plots did not differ in either season (Fig. 6).

Table 2. Results of univariate ANOVA of cover of dominant grass species.

\begin{tabular}{|c|c|c|c|c|c|c|}
\hline \multirow[b]{2}{*}{ Source } & \multicolumn{2}{|c|}{ S. cryptandrus } & \multicolumn{2}{|c|}{ Q. hymenoides } & \multicolumn{2}{|c|}{ H. jamesii } \\
\hline & MS & $\mathbf{P}$ & MS & $\mathbf{P}$ & MS & $\mathbf{P}$ \\
\hline Time & 59.35 & $<0.001$ & 126.12 & $<0.001$ & 31.67 & $<0.001$ \\
\hline Graze & 15.32 & 0.041 & 0.47 & 0.649 & 3.14 & 0.460 \\
\hline Time* graze & 1.51 & 0.800 & 4.54 & 0.094 & 1.28 & 0.926 \\
\hline Season & 22.98 & 0.012 & 4.67 & 0.152 & 134.99 & $<0.001$ \\
\hline Time*season & 1.89 & 0.725 & 2.11 & 0.449 & 2.53 & 0.780 \\
\hline Graze*season & 0.54 & 0.700 & 1.18 & 0.472 & 0.86 & 0.699 \\
\hline Time*graze*season & 0.71 & 0.942 & 0.54 & 0.917 & 0.48 & 0.988 \\
\hline Error & 3.66 & & 2.28 & & 5.76 & \\
\hline
\end{tabular}
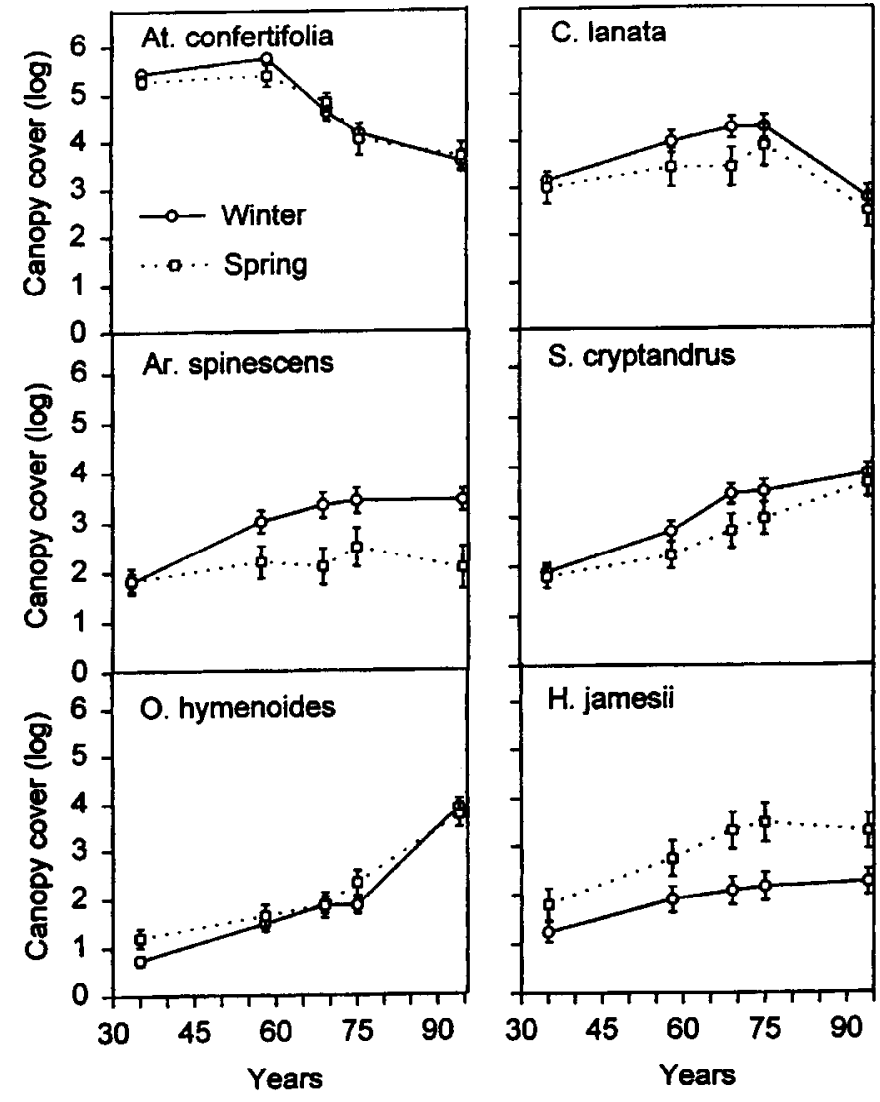

Fig. 5. Season $\times$ time effects on log-transformed cover of 6 dominant species at the DER. Note that season is the main effect and thus includes both grazed plots and ungrazed control companion plots. It is therefore strictly a comparison of pastures assigned to a given season, not a comparison of spring-grazed versus wintergrazed. Vertical bars are standard errors of the mean. Although these SEs reliably represent dispersion of the data, probabilities reported in the tables and text are more valid and meaningful regarding mean separations.

\section{Shrub-Grass Interface}

Time was significant as a multivariate effect $(\mathrm{P}<0.001)$ and as a univariate effect for both shrubs $(\mathrm{P}<0.001)$ and grasses $(\mathrm{P}<$ $0.001)$. Shrub cover increased between 1935 and $1958(\mathrm{P}<$ 0.001 ), remained unchanged through 1975 , then declined substantially by 1994 ( $P<0.001$, Fig. 7). Grass cover increased between 1935 and $1958(\mathrm{P}<0.001), 1958$ and $1969(\mathrm{P}=0.004)$, and 1975 and $1994(\mathrm{P}<0.001)$.

\section{Discussion and Conclusions}

\section{Total Plant Cover Dynamics}

Prior to 1935, the DER was assumed to have been degraded due to uncontrolled grazing (McArdle et al. 1936, Stewart et al. 1940, Shantz and Piemeisel 1940) coupled with drought (Branson 1985, Alzérreca-Angelo 1996). Following improvement in management and climatic factors, plant cover increased (Hutchings and Stewart 1953, Harper 1959, Holmgren and Hutchings 1972, Norton 1978, Norton and Bermant 1977). The total cover increase was maintained through the 1950s-1970s dry cycle, with controlled grazing, and with substantial die-off of shrubs (Harper et al. 1990, Alzérreca-Angelo 1996). 

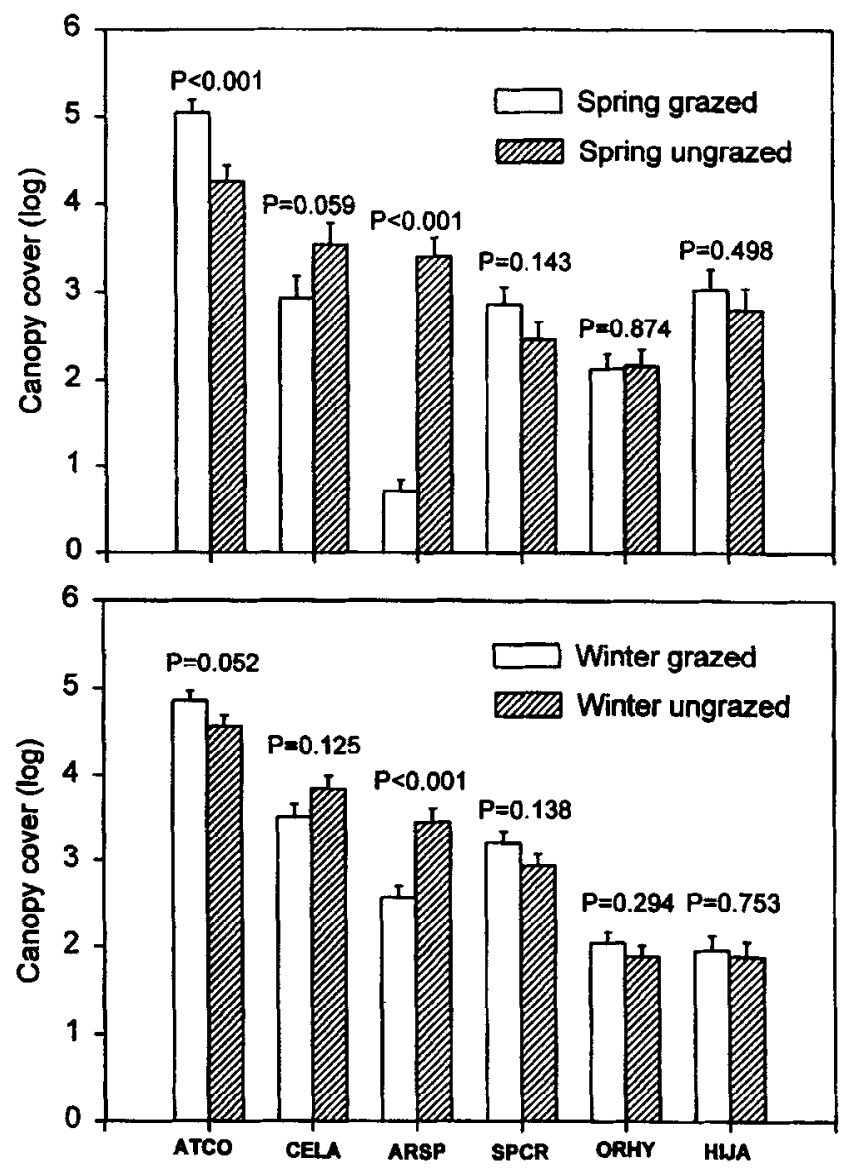

Fig. 6. Effects of grazing on log-transformed cover by species and by season at the DER. Values are mean covers over the 5 sample dates and therefore show the overall grazing effect by season. Vertical bars are standard errors of the mean. Although these SEs reliably represent dispersion of the data, probabilities reported in the tables and text are more valid and meaningful regarding mean separations. ATCO $=$ Atriplex confertifolia, CELA $=$ Ceratoides lanata, $\mathbf{A R S P}=$ Artemisia spinescens, $\mathbf{S P C R}=$ Sporobolus cryptandrus, ORHY = Oryzopsis hymenoides, and HIJA $=$ Hilaria jamesii.

The role of controlled grazing in total cover dynamics was significant, but less than expected. Grazed plots did not surpass ungrazed plots in total cover until 1975, and cover of the 2 treatments did not diverge further by 1994 . These results are compatible with other exclosure studies of salt desert shrub communities showing limited evidence of grazing effects on vegetation (Turner 1971, Rice and Westoby 1978). Branson (1985) and others suggest vegetation change in these extreme environments is slow. Results of this study and others (Turner 1971), however, suggest that total plant cover can increase or decrease rapidly. What appears to be difficult is the detection of a major effect of controlled grazing, which may be evident only after long-term herbivory.

Much of the total cover dynamics appear to be linked to climate. Increasing cover between 1935 and 1958 coincided with increased precipitation (Alzérreca-Angelo 1996), the lack of change between 1959 and 1969 coincided with a return to drier than average conditions, especially during winter, and decreasing cover between 1975 and 1994 occurred with increasing precipita- tion, which may have been especially harmful to shrubs (Pyke and Dobrowolski 1989). Puzzling changes between 1969 and 1975 , however, show the complexity of vegetation change. Total cover in ungrazed plots increased during the driest period of the study. This increase is explained by growth rather than recruitment (Harper et al. 1990, Alzérreca-Angelo 1996), but it is uncertain why the increase occurred under such dry conditions. Independent of cause, the significant divergence in cover between grazing treatments at this time suggests a greater grazing effect in dry than in wet years.

$\Lambda$ final point concerns the suitability of non-grazed controls. By later stages of this study, ungrazed pastures were probably affected more by competition, climate, and small animal activity than by release from grazing pressure decades before. The lack of large herbivore activity for 59 years in the exclosures has perhaps resulted in a plant community that is not necessarily appropriate for comparisons with grazed pastures. Some degree of large animal herbivory is a natural component of the plant community in any rangeland.

\section{Individual Species Cover Dynamics}

Dominant species showed different responses to time and grazing. As with total cover, release from overgrazing, continued controlled grazing, and climate all contributed to, but do not completely explain, observed vegetation dynamics.

\section{Atriplex confertifolia}

Atriplex confertifolia, the least palatable of the shrubs (Chambers and Norton 1993) and the dominant species in 1935,

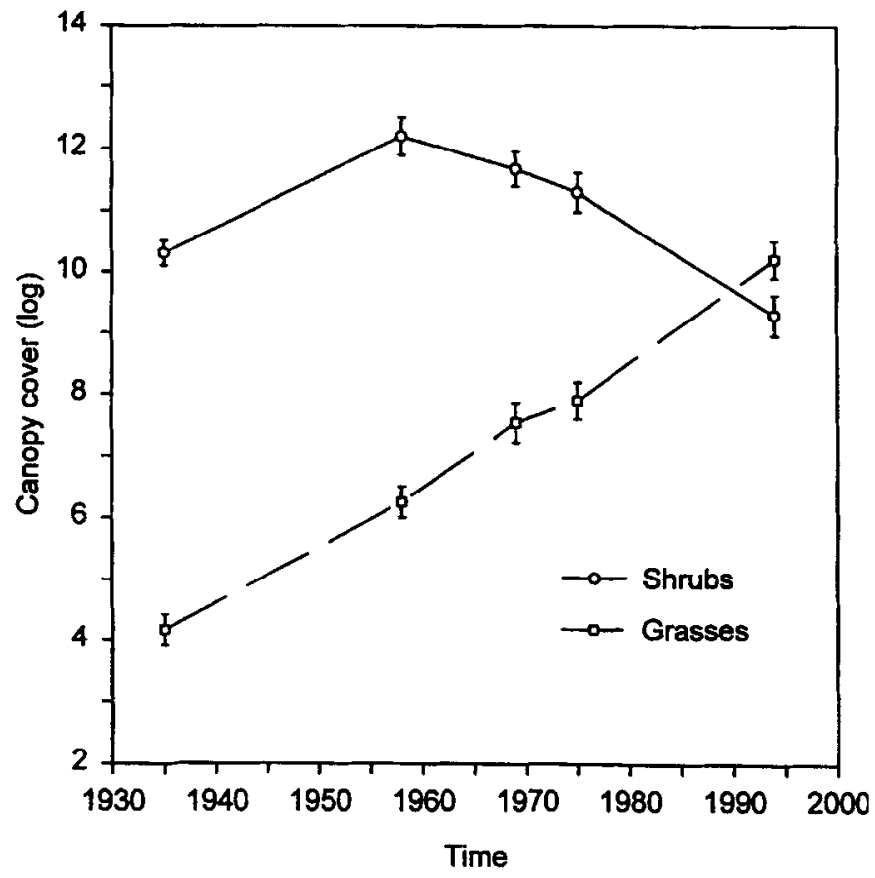

Fig. 7. Log-transformed cover of shrubs and grasses over time at the DER based on the six dominant species considered in this study. Vertical bars are standard errors of the mean. Although these SEs reliably represent dispersion of the data, probabilities reported in the tables and text are more valid and meaningful regarding mean separations. 
did not increase following release from uncontrolled grazing. Holmgren and Hutchings (1972) suggested shadscale dominance was due to over-exploitation of the range prior to 1935 , and that it would eventually retreat under moderate grazing as more palatable species recovered. In fact, shadscale cover decreased equivalently with and without controlled grazing, with only the rate of decrease being associated with grazing. This is compatible with the view that intense grazing increases the less palatable component of vegetation due to release from competition and herbivoremediated increases in nutrient cycling (Archer and Smeins 1991, Pieper 1994, Beeskow et al. 1995).

\section{Ceratoides lanata}

In previous studies, cover of this palatable $\mathrm{C}_{3}$ shrub increased in ungrazed and winter-grazed pastures (Harper 1959, Holmgren and Hutchings 1972, Norton and Bermant 1977, Norton 1978), but decreased in pastures heavily grazed in spring (Holmgren and Hutchings 1972, Blaisdell and Holmgren 1984). Although our design differed from these studies, our results are similar. Despite a significant grazing effect, however, dramatic changes occurred regardless of grazing. By extending the study to 1994 , we observed a dramatic decrease in cover of both grazed and ungrazed plots.

In addition to grazing, winterfat dynamics may be influenced by aging, climate, competition, and changes in soil microbe communities (Norton 1978; Harper et al. 1990, 1996; AlzérrecaAngelo 1996). By 1975, more than half of the winterfat population was at least 40 years old (Norton 1978). With an estimated 50-year life expectancy (Chambers and Norton 1993), increased mortality after 1975 (Harper et al. 1990) was not surprising, and may have been exacerbated by stress. Winterfat has an extensive fibrous root system and a taproot that penetrates deeply into the soil (6-7 m, Stevens et al. 1977). These morphological adaptations to drought may have made winterfat susceptible to the relatively wet $1975-94$ conditions. There is also limited evidence that competition from increasing herbaceous populations may have further stressed weakened winterfat plants (Alzérreca-Angelo 1996, Harper et al. 1996). Finally, large increases in alien annuals late in the study appear to be linked to increased winterfat seedling mortality via changes in soil microbe populations (Harper et al. 1996)

\section{Artemisia spinescens}

Artemisia spinescens dynamics appear to be driven more by grazing than climate. The response of this $C_{3}$ shrub depended heavily on whether it was grazed or not, and on season of grazing. This highly palatable shrub (Chambers and Norton 1993) responded markedly to complete release from sheep grazing, but even controlled grazing retained cover at 1935 levels. Additionally, spring grazing was especially harmful, probably because sheep prefer fresh forage in spring when this species is succulent, physiologically active, and more susceptible to harm (Wood 1966, Chambers and Norton 1993). Comparable results until 1975 were reported by Hutchings and Stewart (1953), Harper (1959), Holmgren and Hutchings (1972), Norton and Bermant (1977), and Norton (1978). In contrast to other shrubs in this study, budsage did not show a decrease in cover over the wet 1975-1994 interval.

\section{Sporobolus cryptandrus}

Cover of this warm-season grass (Waller and Lewis 1979) appears to have responded largely to climate, increasing over intervals with above average summer precipitation. Between 1935 and 1958, however, cover increased with below average summer precipitation, suggesting the initial recovery might be due to relaxing uncontrolled grazing. Controlled winter and spring grazing may also provide a competitive advantage to this and other species that remain dormant throughout that portion of the grazing season. Shrubs at the DER appanently interfere with establishment of dominant grasses (Alzérreca-Angelo 1996), and the increased cover of $S$. cryptandrus corresponded temporally with decreasing cover of At. confertifolia and C. lanata and spatially with lower cover of Ar. spinescens and C. lanata in grazed plots.

\section{Oryzopsis hymenoides}

Cover increases of this cool-season $\mathrm{C}_{3}$ grass appear to be due to release from uncontrolled grazing initially and to intervals with favorable winter precipitation throughout the study. As with $\mathbf{S}$. cryptandrus, the large increase over our last interval may have been facilitated by reduced competition from shrubs. Compatible with this interpretation, Chambers and Norton (1993) reported higher rates of $O$. hymenoides mortality in shrub-dominated than in grass-dominated pastures.

\section{Hilaria jamesii}

Cover of this warm-season grass (Waller and Lewis 1979) increased following initial cessation of uncontrolled grazing, but then stabilized, showing no response to climate. In combination with $S$. cryptandrus, the initial increase suggests that even grazing-season dormant species may benefit from the imposition of controlled grazing. The reason for the benefit is uncertain, however; $\boldsymbol{H}$. jamesii cover increased when compctition from other species was reduced by heavy (Harper 1959, Gutierrez-Garza 1978) and spring grazing (this study), suggesting it should not have shown strong recovery after 1935 . Perhaps uncontrolled grazing prior to 1935 included occasional abusive summer use despite a general scarcity of water. In summary, results suggest that under present grazing conditions cover dynamics of $H$. jamesii may be driven largely by competition, and that the initial increase was not sustained due to an increase in other grasses through time.

\section{Shrub-Grass Interface}

Shrubs and grasses responded quite differently through the study. Shrubs, a major component of the community in 1935, initially increased in cover but quickly stabilized before dramatically decreasing during the wet 1975-94 interval. In contrast, grass cover was initially very low and, except over the shortest and driest 1969-75 interval, steadily increased throughout the study. Grass cover is now roughly equal to shrub cover. Although cover changes are complex, above average precipitation likely played a role in the major changes between 1975 and 1994; shrubs are less tolerant than grasses of wet conditions and associated problems (Pyke and Dobrowolski 1989). Interestingly, Holmgren and Hutchings (1972) suggested that a trend towards grassland is a common response of many salt desert shrub communities to winter and spring overgrazing. This long-term data set, however, reveals a dramatic shift from a shrubland to a mixed shrub-grassland both with and without controlled grazing. Clearly, conversion to grassland in these systems is not simply a function of grazing. 


\section{General Discussion and Conclusions}

In general, the interval from 1935 to 1958 can be characterized as a period of range recovery. Without a treatment mimicking original "uncontrolled" conditions it is not possible to quantify the relative importance of climate (Norton and Bermant 1977, Norton 1978, Norton and Michalk 1978) and relaxation of uncontrolled grazing (McArdle et al. 1936, Shantz and Piemeisel 1940, Stewart et al. 1940) in this recovery. In reality, although the relative importance of these factors appears to vary with species, both were prohably important. Change in management set the stage for recovery and changes in climate allowed recovery to occur.

From 1958 on, however, we suggest that although grazing has continued to influence plant cover, its importance has diminished relative to that of climatic effects and inherent plant characteristics such as aging, establishment ecology, and stress tolerance. For total cover and for many individual species, grazing appears to have affected the rate more than the direction of change. This fits the growing realization that climate can cause rapid shifts in rangeland vegetation that may or may not interact with grazing effects (Western and Van Praet 1973, Chew 1982, Hennessy et al. 1983, Sharp et al. 1990, Archer and Smeins 1991, O'Connor and Roux 1995, Harper et al. 1996). Additionally, we suggest that with appropriate management, grazing in these systems may have only relatively minor effects on vegetation cover.

A final issue concerns models of vegetation change and range condition. We interpret the results of this study as not supporting the classical range succession model (sensu Westoby et al. 1989) of Clements (1916). Although changes in total and individual species cover up to 1976 could be argued to be on a successional trajectory triggered by release from severe grazing, continued changes to the present argue against steady linear succession to a climax. Alternatively, Laycock $(1991,1994)$ suggested the salt desert vegetation may be an example of a steady state in a stateand-transition model of vegetation change (sensu Westoby et al. 1989). Although more realistic, it is not clear that the shadscale community is a stable state. Despite early evidence of little vegetation change (Turner 1971, Rice and Westoby 1978), shadscale communities are in reality quite dynamic. Our results and those of Sharp et al. (1990) do not reveal shifts across a threshold from 1 relatively stable state to another. Instead, the community appears to drift through time, pushed by climatic variation, insect outbreaks, competitive relationships, inherent demographic properties, and grazing. If the community is in a stable state, the state has to he viewed as very broad. The patterns are more compatible with Friedel's (1991) view of environmental variability continuously shifting a site among a variety of short-lived states. In the present-day salt desert, however, a likely shift to a new stable state may be found in the conversion to exotic annual weed communities (Kitchen and Hall 1996).

\section{Literature Cited}

Alzérreca-Angelo, H. 1996. Spatial and temporal dynamics of plant populations in salt-desert shrub vegetation grazed by sheep. Ph.D. Thesis, Utah State Univ., Logan, Utah.

Archer, S. and F.E. Smeins. 1991. Ecosystem-level processes, p. 109-139. In: R.K. Heitschmidt and J.W. Stuth (eds.), Grazing management an ecological perspective. Timber Press, Portland, Ore.

Beeskow, A.M., N.O. Elissalde, and C.M. Rostagno. 1995. Ecosystem changes associated with grazing intensity on the Punta Ninfas rangelands of Patagonia, Argentina. J. Range Manage. 48:517-522.
Blaisdell, J.A. and R.C. Holmgren. 1984. Managing Intermountain rangelands-salt desert shrub ranges. USDA For. Serv. Gen. Tech. Rep. INT-163, Ogden, Utah.

Branson, F.A. 1985. Vegetation changes on western rangelands. Range Monogr. No. 2, Soc. for Range Manage., Denver, Colo.

Brewster, S.F. 1968. A study of the effectiveness of precipitation in the salt desert shrub type. M.S. Thesis, Brigham Young Univ., Provo, Utah.

Chambers, J.C. and B.E. Norton. 1993. Effects of grazing and drought on population dynamics of salt desert shrub species on the Desert Experimental Range, Utah. J. Arid Environ. 24:261-275.

Chew, R.M. 1982. Changes in herbaceous and suffrutescent perennials in grazed and ungrazed desertified grassland in southeastern Arizona, 1958-1978. Amer. Midl. Natur. 108:159 169.

Clary, W.P. and R.C. Holmgren. 1987. Difficulties in interpretation of long-term vegetation trends in response to livestock grazing, $p$ 154-161. In: F.D. Provenza, J.T. Flinders, and E.D. McArthur (compilers). Proceedings-Symposium on plant-herbivore interactions. USDA For. Serv. Gen. Tech. Rep. INT-GTR 222, Ogden, Utah.

Clements, F.E. 1916. Plant succession: an analysis of the development of vegetation. Carnegie Inst. Washington Pub. 242:1-512.

Friedel, M.H. 1991. Range condition assessment and the concept of thresholds: a viewpoint. J. Range Manage. 44:422-426.

Gardiner, H.G. and B.E. Norton 1983. Do traditional methods provide a reliable measure of range trend, p. 618-622. In: J.F. Bell and T. Atterbury (eds.), Proceedings of international conference on renewable resource inventories for monitoring changes and trends, Oregon State University, Corvallis, Ore.

Goodrich, S. 1986. Vascular plants of the Desert Experimental Range, Millard County, Utah. USDA Forest Serv. Gen. Tech. Rep. INT-209, Ogden, Utah.

Gutierrez-Garza, J.S. 1978. Potential for cattle grazing on sheep range in southwest Utah. M.S. Thesis, Utah State Univ., Logan, Utah.

Harper, K.T. 1959. Vegetation changes in a shadscale-winterfat plant association during 23 years of controlled grazing. M.S. Thesis, Brigham Young Univ., Provo, Utah.

Harper, K.T., R. Van Buren, and S.G. Kitchen. 1996. Invasion of alien annuals and ecological consequences in salt desert shrublands of western Utah, p 56-65. In: J.R. Barrow, E.D. McArthur, R.E. Sosebee, and J.R. Tausch (Compilers). Proceedings-Symposium on shrubland ecosystem dynamics in a changing environment. USDA For. Serv. Gen. Tech. Rep. INT-338, Ogden, Utah.

Harper, K.T., F.J. Wagstaff, and P.C. Warren. 1990. Shrub mortality over a 54-year period in shadscale desert, west-central Utah, p. 119-126. In: E.D. McArthur, E.M. Romney, S.D. Smith, and P.T. Tueller (compilers). Proceedings-Symposium on cheatgrass invasion, shrub die-off, and other aspects of shrub biology and management. USDA For. Ser. Gen. Tech. Rep. INT-276, Ogden, Utah.

Hatcher, L., and E.J. Stepanski. 1994. A step by step approach to using the SAS system for univariate and multivariate statistics. SAS Institute Inc., Cary, N.C.

Hennessy, J.T., R.P. Gibbens, J.M. Tromble, and M. Cardenas. 1983. Vegetation changes from 1935 to 1980 in mesquite dunelands and former grasslands in southern New Mexico. J. Range Manage. 36:370-374

Holmgren, R.C. 1973. The Desert Experimental Range: description, history and program, p. 18-22 In: Arid shrublands. Proceedings of the third workshop of the U.S./Australian rangelands panel. Soc. Range Manage., Denver, Colo.

Holmgren, R.C. and S.S. Hutchings. 1972. Salt desert shrub response to grazing use, p. 153-164. In: C.M. McKell, J.P. Blaisdell, and J.R. Goodin (compilers), Wildland shrubs-their biology and utilization. USDA For. Ser. Gen. Tech. Rep. INT-1, Ogden, Utah.

Hutchings, S.S. 1966. Grazing management of salt-desert shrub ranges in the western United States, p. 1,619-1,625. In: Proceedings ninth international grassland congress.

Hutchings, S.S. and G. Stewart. 1953. Increasing forage yields and sheep production on Intermountain winter ranges. USDA Circ. 925, Ogden, Utah. 
Kitchen, S.G. and D.B. Hall. 1996. Community stability in a salt-desert shrubland grazed by sheep: the Desert Experimental Range story, p. 102-107. In: J.R. Barrow, E.D. McArthur, R.E. Sosebee, and J.R. Tausch (Compilers), Proceedings-Symposium on shrubland ecosystem dynamics in a changing environment. USDA For. Ser. Gen. Tech. Rep. INT-GTR 338, Ogden, Utal.

Laycock, W.A. 1991. Stable states and thresholds of range condition on North American rangelands: a viewpoint. J. Range Manage. 44:427-433.

Laycock, W.A. 1994. Implications of grazing vs. no grazing on today's rangelands, p. 250-280. In: M. Vavra, W.A. Laycock, and R.D. Pieper (eds.), Ecological implications of livestock herbivory in the West. Soc. Range Manage., Denver, Colo.

Marble, J.R. 1990. Rangeland microphytic crust management: distribution, grazing impacts, and mineral nutrition relations. Ph.D. Thesis, Brigham Young Univ., Provo, Utah.

McArdle, R.E., D.F. Costello, and E.E. Birkmaier. 1936. The white man's toll. In: The western range. Sen. Doc. 199, 74th Congr. U.S. Government Printing Office, Washington, D.C.

Norton, B.E. 1978. The impact of sheep grazing on long-term successional trends in salt desert shrub vegetation of southwestern Utah, $p$. 610-613. In: D.N. Hyder (ed.), Proceedings First International Rangeland Congress. Soc. Range Manage., Denver, Colo.

Norton, B.E. and B.E. Bermant. 1977. Plant replacement and population interactions of perennials in salt desert shrub vegetation. Transcript of paper presented at AIBS Annual meeting, Aug. 21-26 1977, East Lansing, Mich.

Norton, B.E. and D.L. Michalk. 1978. Some theorems for Range Science. Transcript of paper presented at the 31st Annual Meeting Soc. for Range Manage., Feb. 7-9, San Antonio, Tex.

O'Connor, T.G. and P.W. Roux. 1995. Vegetation changes (1949-1971) in a semi-arid, grassy dwarf shrubland in the Karoo, South Africa: influence of rainfall variability and grazing by sheep. J. Appl. Ficol. 32:612-626.

Pieper, R.D. 1994. Ecological implications of grazing, p. 177-212. In: M. Vavra, W.A. Laycock, and R.D. Pieper (eds.), Ecological implications of livestock herbivory in the West. Soc. Range Manage, Denver, Colo.

Pyke, D.E. and J.P. Dobrowolski. 1989. Shrub dieback in the Great Basin. Utah Science, Summer 1989:66-71.

Rice, B. and M. Westoby. 1978. Vegetative responses of some Great Basin shrub communities protected against jackrabbits or domestic stock. J. Range Manage. 31:28-34.

SAS Institute Inc. 1988. SAS procedures guide, Release 6.03 Edition. Cary, N.C: SAS Institute Inc., 441 pp.

Shantz, H.L. and R.L. Piemeisel. 1940. Indicator significance of the natural vegetation of the southwestern desert region. J. Agr. Res. 28:721-801.

Sharp, L.A., K. Sanders, and N. Rimbey. 1990. Forty years of change in a shadscale stand in Idaho. Rangelands 12:313-328.

Smith, C.B. 1986. Grazing effects and site factors in relation to grazing use of salt desert shrub vegetation, Desert Experimental Range, Utah 1938-1974. M.S. Thesis, Utah State Univ., Logan, Utah.

Stevens, J. 1966. Applied multivariate statistics for social sciences. Lawrence Erlbaum Assoc.. Publ., Mahwah, N.J.

Stevens, R., B.C. Giunta, K.R. Jorgensen, and A.P. Plummer. 1977. winterfat (Ceratoides lanata). Utah State Div. Wildl. Res. Publ. No. 77-2.

Stewart, G., W.P. Cottam., and S.S. Hutchings. 1940. Influence of unrestricted grazing on northern salt desert plant associations in western Utah. J. Agr. Res. 60:289-316.

Tew, R.K., S.G. Kitchen, and R.C. Holmgren. 1997. Soil SurveyDesert Experimental Range, Utah. USDA, For. Ser. Gen.Tech. Rep. INT-GTR 347, Ogden, Utah.

Turner, G.T. 1971. Soil and grazing influences on a salt-desert shrub range in western Colorado. J. Range Manage. 24:31-37.

Waller, S.S. and J.K. Lewis. 1979. Occurrence of $C_{3}$ and $C_{4}$ photosynthetic pathways in North American grasses. J. Range Manage. 32:12-28.
West, N.E. 1979. Survival patterns of major perennials in salt desert shrub communities of southwestern Utah. J. Range Manage. 32:442-445.

Western, D. and C. Van Praet. 1973. Cyclical changes in the habit and climate of an east African ecosystem. Nature 241:104-106.

Westoby, M., B. Walker, and I. Noy-Meir. 1989. Opportunistic range management for rangelands not at equilibrium. J. Range Manage. 42:266-274.

Wood, B.W. 1966. An ecological life history of budsage. M.S. Thesis, Brigham Young Univ., Provo, Utah.

Whisenant, S.G. and F.G. Wagstaff. 1991. Successional trajectories of a grazed salt-desert shrubland. Vegetatio 94:133-140.

\section{United States Department of Agriculture Center Director \\ Subtropical Agricultural Research Center}

The Agriculture Research Service is seeking applications for the position of Center Director for the Subtropical Agricultural Research Center, Weslaco, TX. Weslaco is uniquely located in the Lower Rio Grande Valley in a major agricultural region and near major crossing points of the international horder with Mexico. The Center Director provides direction to three research units, manages the extensive facilities, is accountable for all funds and federally owned property, and serves as a contact point for cooperative research with Texas A\&M University and organizations in Latin America. Staff at the center number about 125 full-time equivalents including 30 research scientists. Research conducted by the Center is a part of the National Research Program of the Agricultural Research Service. Major research areas include development of control strategies for posts of major agronomic importance to cotton, fruit, and vegetables; development of sustainable integrated cropping systems that are well adapted to the region; and development of technology to protect quality of citrus fruits and vegetables. The incumbent must be a U.S. citizen and have education specialized experience related to the position. Salary is commensurate with experience, GS$15(\$ 76 \mathrm{~K}-\$ 99 \mathrm{~K})$. For application information and forms, contact Tommy Stanford, USDA, ARS, SPA, SARC, 2301 S. International Blvd., Weslaco, Tx. 78596. Telephone: 956/565-2606 or E-mail: sarcjob@ rsru2.tamu.edu. For complete vacancy announcement see Internet site at http://www.ars.usda.gov/afm/hrd/vacancy/d8s-8093.htm. Applications in response to this advertisement should be marked ARS-D8S-8093(S-8-010). Applications must be postmarked by April 24, 1998. ARS is an equal opportunity employer. Women and minorities are encouraged to apply. 